\title{
Lulur Gosok Tradisional BERSERI (Beras, Serai Wangi, Kunyit) sebagai Antioksidan
}

\author{
Rahmadevi $^{1}$, Fitriani Arin ${ }^{2 *}$, Oktaviani Puspita ${ }^{3}$, Armayana Firda $^{4}$, Yasnawati $^{5}$ \\ ${ }^{1-5}$ Program Studi Farmasi, STIKES Harapan Ibu Jambi \\ *e-mail: arinfitriani0@gmail.com
}

Submitted : $17 / 06 / 2020$

Accepted: 01/07/2020

Published: 24/11/2020

\begin{abstract}
Traditional body scrubis one cosmetic sedian that is made from fresh natural or ingredients that have been dried from plants and fruit. The basic ingredient of making scrubs commonly used in traditional cosmetics is rice flour. Rice has a rich content of protein, vitamins, minerals and water. The content found in rice flour is gamma oryzanol. And this compound can renew the formation of melanin pigment, as an antioxidant and also effective to ward off ultrafiolet rays. Besides turmeric also has activity as an antioxidant derived from kukumin contained in turmeric. Lemongrass also gives romatherapy to the body scrub because it contains essential oils which give a distinctive odor. The purpose of this research is to increase the knowledge of the women of Lubuk Dalam Hamlet on Traditional Scrub Scrub derived from rice and spices such as turmeric which has antioxidant activity and Lemongrass that can give aromatherapy to the scrub. This community service method uses a participatory method that involves the community of Kemingking Dalam Village. The results of this study found that the increased knowledge of the community of Kemingking Dalam Village regarding the efficacy and ways of making scrubs derived from rice, turmeric and lemongrass.
\end{abstract}

Keywords: antioxidant, body scrub, lemongrass, turmeric

\begin{abstract}
Abstrak
Lulur tradisional merupakan salah satu sedian kosmetik yang berbahan dasar alami segar atau bahan yang sudah dikeringkan dari tanaman dan buah. Bahan dasar pembuatan lulur yang biasa digunakan pada kosmetik tradisional adalah tepung beras. Beras memiliki kandungan yang kaya akan protein,vitamin, mineral dan air. Kandunagn yang terdapat pada tepung beras adalah gamma oryzanol. Senyawa ini dapat memperbaharui pembentukan pigmen melanin, sebagai antioksidn dan juga efektif untuk menangkal sinar ultraviolet. Selain itu kunyit juga memiliki aktivitas sebagai aktioksidan yang berasal dari kukumin yang terdapat dalam kunyit. Serai wangi juga memberikan aromaterapi pada lulur karena mengandung minyak atsiri yang memberikan bau yang khas. Tujuan penelitian ini untuk meningkatkan pengetahuan ibu-ibu Dusun Lubuk Dalam tentang Lulur Gosok Tradisional yang berasal dari beras dan rempah-rempah seperti kunyit yang memiliki aktivitas sebagai antioksidan dan Serai Wangi yang dapat membrikan aroma terapi pada lulur. metode pangabdian masyarakat ini menggunakan metode partisipari yang melibatkan masyarakat Desa Kemingking Dalam. Hasil penelitian ini didapatkan bahwa meningkatnya pengetahuan masyarakat Desa Kemingking Dalam mengenai khasiat dan cara pembuatan lulur yang berasal dari beras, kunyit dan serai wangi.
\end{abstract}

Kata Kunci: antioksidan, kunyit, lulur, serai wangi

\section{PENDAHULUAN}

Penuaan kulit merupakan salah satu proses alami yang tidak dapat dihindari, dimana sel manusia akan mengalami kelemahan proses pembaruan sel baru sehingga kulit dan produksi kolagen serta melemahnya struktur pendukung internal dan lapisan pelindung alami kulit (Ramadhania, Rjitraresmi, \& Nuwarda, 2018). Faktor yang menjadi penyebab melambatnya pembaruan sel dikarenakan lingkungan dan stres oksidatif intraseluler dan ekstraseluler yang diakibatkan oleh reactive oxygen species (ROS) sehingga mempercepat penuaan kulit yang ditandai dengan keriput dan pigmentas kulit (Masaki, 2010). Antioksidan bekerja secara sinergis untuk menstabilkan peran 
ROS pada proses photoaging, karsinogenesis dan inflamasi (Andarina \& Djauhari, 2017).

Perawatan tubuh berupa lulur dapat memberikan manfaat melembabkan dan mencerahkan kulit (Riwayani, n.d.). Lulur tradisional merupakan salah satu sediaan kosmetik yang berbahan dasar alami segar atau bahan yang sudah dikeringkan dari tanaman dan buah (Erlinawati et al., 2018). Kosmetik tradisional menggunakan bahanbahan herbal sebagai bahan aktif dalam sedian kosmetik (Cahyanto, 2017). Bahan dasar pembuatan lulur yang biasa digunakan pada kosmetik tradisional adalah tepung beras (Erlinawati et al., 2018).

Tepung beras dipercaya dapat
berfungsi untuk meningkatkan elastisitas kulit (Christina, 2011). Beras memiliki kandungan yang kaya akan protein, vitamin, mineral dan air. Kandungan yang tedapat pada tepung beras adalah gamma oryzanol. Kandungan senyawa ini dapat memperbaharui pembentukan pigmen melanin, sebagai antioksidan dan juga efektif untuk menangkal sinar ultraviolet (Erlinawati et al., 2018).

Selain bahan dasar beras, lulur tradisional juga dapat menambahkan bahan tambahan lainnya yang berasal dari rempahrempah. Salah satu rempah yang dapat digunakan untuk bahan pembuatan lulur adalah kunyit (Cahyanto, 2017). Kunyit dipercaya memiliki kandungan kimia yang penting dari rimpang kunyit adalah kurkumin, minyak atsiri, resin, desmetoksi kurkumin, oleoresin, dan damar, gom, lemak, protein, kalsium, fosfor dan besi. Kurkumin dalam kuyit memiliki aktivitas sebagai antioksidan (Yuan Shan \& Iskandar, 2018). Fungsi lain kunyit dalam kosmetik lulur yaitu untuk menghaluskan dn memberi warna kunging langsat (Cahyanto, 2017).

Selain kunyit, serai wangi juga merupakan rempah yang dapat di ambil minyaknya dan digunakan menjadi formula pembuatan lulur tradisional yang berfungsi sebagai aromaterapi. Serai wangi juga memiliki kandungan minyak atsiri yang dapat menyegarkan kulit dan membuat lebih nyaman (Prabandari \& Febriyanti, 2017). Dari berbagai tanaman obat yang ada, sereh wangi (Cymbopogon nardus L.) merupakan salah satu tanaman yang memiliki banyak manfaat. Hasil penyulingan daun dan batang sereh wangi diperoleh minyak atsiri yang dalam dunia perdagangan dikenal dengan nama Citronella Oil (Bota \& Martosupono, 2015).

Dalam jurnal penelitian (Erlinawati et al., 2018) dilakukan penelitian pembuatan lulur yang berasal dari bahan dasar beras dan kunyit putih sebagai antioksidan. Dengan begitu peneliti tertarik melakukan penelitiaan pemanfaatan bahan pangan dan rempahrempah menjadi suatu produk kosmetik tradisional yang dapat dibuat oleh ibu-ibu rumah tangga secara mandiri. Karena pemafaatan rempah-rempah ini cukup jarang dilakukan oleh ibu-ibu rumah tangga untuk dijadikan sebagai kosmetik tradisional.

Penelitian ini bertujuan untuk meningkatkan pengetahuan ibu-ibu Dusun Lubuk Dalam tentang Lulur Gosok Tradisional yang berasal dari beras dan rempah-remah seperti kunyit yang memiliki aktivitas sebagai antioksidan dan Serai Wangi yang dapat memberikan aroma terapi pada lulur.

\section{TARGET DAN LUARAN}

1. Target

Seluruh lapisan masyarakat Dusun Lubuk Dalam terutama kalangan ibu-ibu rumah tangga dan para pemuda-pemudi di Dusun Lubuk Dalam Rt 03.

\section{Luaran}

Terselesaikannya kegiatan pemahaman masyarakat terkait tata cara pemanfaatan tanaman herbal berkhasiat yang berada di sekitar lingkungan sehingga dapat menjadi sebuah produk kosmetik kecantikan alami yang nantinya dapat aplikasikan dikehidupan sehari-hari. 


\section{METODE PELAKSANAAN}

Metode pengabdian masyarakat yang dilakukan yaitu metode partisipatori, dimana peran dan partisipasi masyarakat dilibatkan secara langsung dalam proses kegiatan ini dan melakukan penyuluhan yang meliputi ceramah, tanya jawab dan penyuluhan serta demonstrasi praktik produk lulur berseri.

\begin{tabular}{|c|c|c|c|}
\hline No & Tahapan & Kegiatan & Metode \\
\hline 1 & Survei & $\begin{array}{c}\text { Survey lokasi dan } \\
\text { observasi } \\
\text { permasalahan yang } \\
\text { terdapat di Desa } \\
\text { Kemingking Dalam } \\
\text { Dusun Lubuk Dalam } \\
\text { Menyiapkan alat dan } \\
\text { bahan yang diperlukan } \\
\text { untuk pembuatan lulur } \\
\text { BERSERI. }\end{array}$ & Observasi \\
\hline 2 & Pembuatan & $\begin{array}{l}\text { Pembuatan lulur } \\
\text { BERSERI hingga } \\
\text { menjadi produk } \\
\text { kosmetik yang siap } \\
\text { digunakan. }\end{array}$ & Eksperimen \\
\hline 3 & Demonstrasi & $\begin{array}{c}\text { Penyuluhan lulur } \\
\text { gosok tradisional } \\
\text { BERSERI (Beras, } \\
\text { Kunyit, Serai Wangi) } \\
\text { sebagai antioksidan }\end{array}$ & $\begin{array}{c}\text { Diskusi dan } \\
\text { Tanya } \\
\text { jawab. }\end{array}$ \\
\hline
\end{tabular}

\section{HASIL DAN PEMBAHASAN}

Tahapan awal yang dilakukan dari kegiatan pengabdian kepada masyarakat ini terlebih dahulu melakukan survei lokasi, observasi permasalahan di lapangan serta penentuan khalayak sasaran. Berdasarkan hasil survei dan wawancara pada beberapa warga dapat diketahui bahwa potensi warga dalam mengolah dan memanfaatkan tanaman herbal berkhasiat masih rendah hal ini disebabkan karna sebagian besar warga desa berprofesi sebagai pekerja di Industri.

Kegiatan utama berupa penyuluhan dan demonstrasi praktik mengolah dilaksanakan selama dua hari yaitu pada tanggal 20 Febuari dan 23 Febuari 2020 di rumah warga yang berlokasi di Desa Kemingking Dalam Dusun Lubuk Dalam Rt 03. Materi yang disampaikan terdiri dari penyampaian khasiat tanaman herbal yang di guankan sebagai bahan produk serta bagaimana cara mengelolah tanaman herbal menjadi produk kosmetik kecantikan yaiu lulur.

Penyuluhan dan demonstrasi ini dilakukan di salah satu rumah warga Dusun Lubuk Dalam. Dimana warga desa yang hadir dapat turut berpartisipasi dalam pembuatan produk oalahan tanaman herbal karena sudah disiapkan seperangkat alat dan bahan khusus bagi warga desa yang ingin turut mencoba.

Prosedur pembuatan produk lulur berseri yang dipraktikan bersama warga yaitu mulai dari pembuatan lulur yaitu dengan cara pembuatan bahan dasar lulur yang berasal dari beras dan kunyit yang dibuat menjadi serbuk lulur kemudian ditambahkan dengan minyak serai wangi yang akan memberikan aromaterapi yang khas dari serai wangi. Sampel rimpang kunyit (Curcuma domesticae rhizoma), serai wangi (Cymbopogon nardus L), dan beras (Oryza sativa L) diperoleh di Desa Kemingking Dalam Dusun Lubuk Dalam. Sampel kemudian di sortir, setelah sampel lulus sortir kemudian sampel di timbang selanjutnya membuat beras dan kunyit menjadi serbuk halus lalu di tambahkan minyak serai wangi masukan kedalam wadah kedap udara. Kemudian lulur dimasukkan kedalam kemasan.

Dari hasil evaluasi diperoleh manfaat yakni hasil dari budidaya tanaman herbal berkhasiat dapat dikelola menjadi lulur BERSERI dengan berbagai manfaat dapat menambah pengetahuan baru tentang pengolahan lulur BERSERI dan meningkatkan kreativitas para ibu-ibu dari Dusun Lubuk Dalam.

Tingkat partisipasi dan antusias warga yang hadir sangat tinggi dapat dilihat dari banyaknya pertanyaan-pertanyaan seputar bagaimana cara mengelola tanaman herbal sehingga menjadi produk lulur dan juga manfaat dari komposisi lulur tersebut. Warga Desa Kemingking Dalam juga mencoba menggunkan lulur BERSERI. 


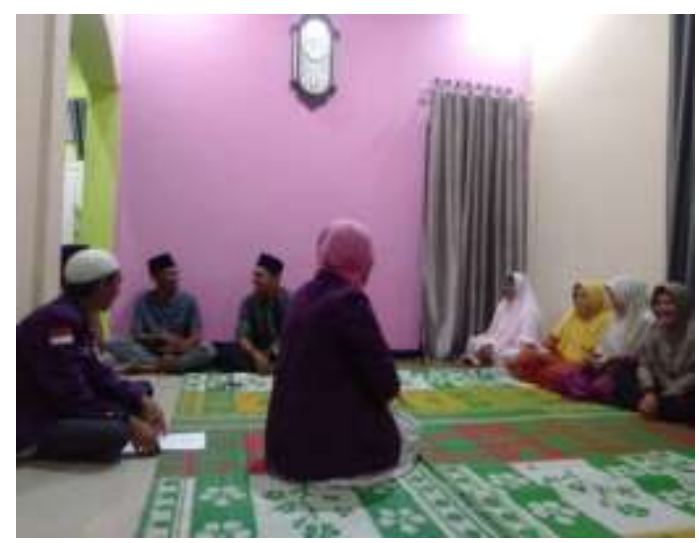

Gambar 1. Demonstrasi kepada warga Dusun Lubuk Dalam

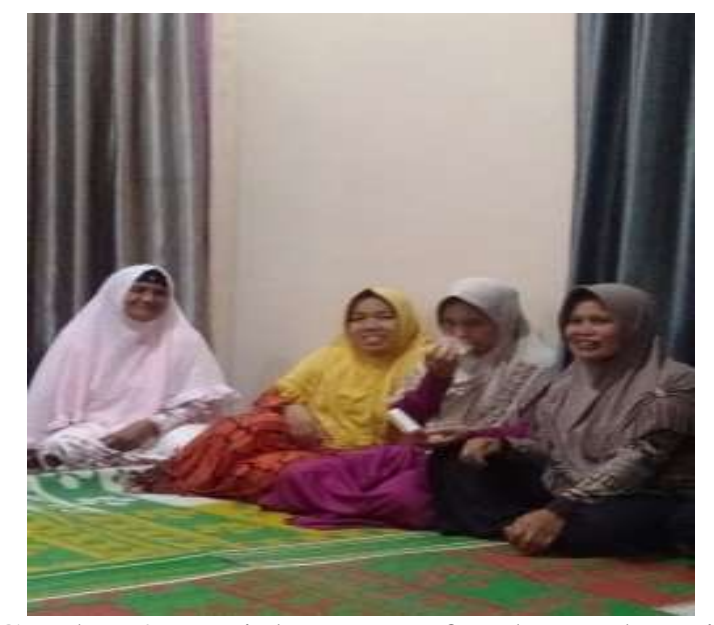

Gambar 2. Penjelasan manfaat beras, kunyit dan serai wangi serta cara penggunaan lulur BERSERI

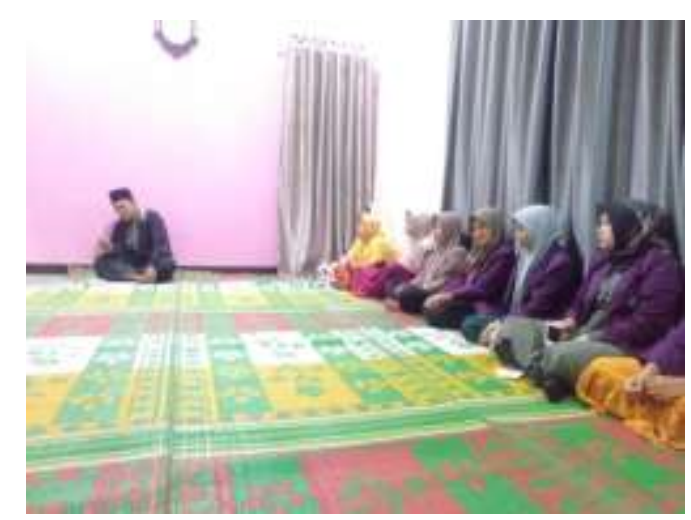

Gambar 3. Tanya jawab dengan masyarakat

\section{KESIMPULAN DAN SARAN}

\section{Kesimpulan}

Berdasarkan pengabdian masyarakat yang dilakukan di Desa Kemingking Dalam didapatkan kesimpulan bahwa :
1. Beras dan Kunyit dapat dibuat menjadi lulur yang memiliki aktivitas antioksidan.

2. Minyak Serai Wangi dapat memberikan bau yang khas untuk lulur BERSERI.

2. Warga Desa Kemingking Dalam sangat antusias untuk mengetahui khasiat dan cara pembuatan Lulur BERSERI

\section{Saran}

Penulis menyampaikan beberapa saran untuk meningkatkan dan mengembangkan hasil penelitian yang telah ditulis, yaitu perlunya ada penelitian lebih lanjut untuk pembuatan lulur gosok tradisional dari bahan dasar beras, kunyit dan serai wangi sebagai antioksidan.

\section{UCAPAN TERIMAKASIH}

Penulis mengucapkan terimakasih kepada STIKES Harapan Ibu Jambi yang telah mendukung kegiatan ini. Penulis mengucapkan terimakasih kepada Kepala Desa Kemingking Dalam beserta jajaran yang telah membantu kegiatan ini. Penulis juga mengucapkan terima kasih kepada seluruh warga Desa Kemingkig Dalam yang telah berpartisipasi. Dan Penulis mengucapkan terima kasih kepada seluruh pihak yang berkontribusi membantu penulis dalam pembuatan Lulur BERSERI.

\section{DAFTAR PUSTAKA}

Andarina, R., \& Djauhari, T. (2017). Antioksidan dalam dermatologi. Jurnal Kimia Dan Kemasan, 4(1), 39-48.

Bota, W., \& Martosupono, M. (2015). Potensi Seyawa Minya Sereh Wangi (Citronella oil) dari Tumbuhan Cymbopogon nardus L. Sebagai Agen Antibakteri. (November), 1-8.

Cahyanto, H. A. (2017). Kualitas dan Keamanan Lulur Berbasis Herbal. Journal Kementerian Perindustrian, 02, $1-4$.

Erlinawati, W. S., Teknik, F., Surabaya, U. 
N., Dwiyanti, S., Pembimbing, D., Keluarga, P. K., ... Surabaya, U. N. (2018). Pengaruh Proporsi Tepung Beras dan Bubuk Kunyit Putih (Curcuma zedoaria Rosc.) Terhadap Hasil Lulur Bubuk Tradisional. 07, 1522.

Masaki, H. (2010). Role of antioxidants in the skin: Anti-aging effects. Journal of Dermatological Science, 58(2), 85-90. https://doi.org/10.1016/j.jdermsci.2010. 03.003

Prabandari, S., \& Febriyanti, R. (2017). Ormulasi Dan Aktivitas Kombinasi Minyak Jeruk Dan Minyak Sereh Pada Sediaan Lilin Aromaterapi. Parapemikir: Jurnal Ilmiah Farmasi, 6(1), 124-126. https://doi.org/10.30591/PJIF.V6I1.48.

Ramadhania, Z. M., Rjitraresmi, A., \& Nuwarda, R. F. (2018). Edukasi dan Pemanfaatan Herbal Sebagai Bahan Kosmetik Alami di Kecematan Ciwaringin Kabupaten Cirebon. 7(3), 189-192.

Riwayani, R. (n.d.). Pemanfaatan Buah Pare Menjadi Tepung Campuran Lulur untuk Perawatan Tubuh Sebagai Bahan Dasar yang Digunakan Pada Mahasiswa PKK FT-UNM. 3(2), 186196.

Yuan Shan, C., \& Iskandar, Y. (2018). Studi Kandungan Kimia Dan Aktivitas Farmakologi Tanaman Kunyit (Curcuma longa L.). Pharmacia, 16, 547-555. 